\title{
A Comparative Study on That Design of Agricultural Canal in Ecological and Traditional Renovation of Agricultural Land-Take a Project Area in Lingchuan County, Guilin City, Guangxi, China as an Example
}

\author{
Yan Zhao, Xiangwen Cai, Yuening Song, Mingyuan Liu, Zehao Liu \\ School of Earth Sciences, Guilin University of Technology, Guilin, China \\ Email: 648088245@qq.com, 598196224@qq.com, 1315643664@qq.com,563970082@qq.com,330364913@qq.com
}

How to cite this paper: Zhao, Y., Cai, X.W., Song, Y.N., Liu, M.Y. and Liu, Z.H. (2021) A Comparative Study on that Design of Agricultural Canal in Ecological and Traditional Renovation of Agricultural Land-Take a Project Area in Lingchuan County, Guilin City, Guangxi, China as an Example. Open Journal of Ecology, 11, 690-699.

https://doi.org/10.4236/oje.2021.1110043

Received: September 23, 2021

Accepted: October 24, 2021

Published: October 27, 2021

Copyright $\odot 2021$ by author(s) and Scientific Research Publishing Inc. This work is licensed under the Creative Commons Attribution International License (CC BY 4.0).

http://creativecommons.org/licenses/by/4.0/

\begin{abstract}
In the current context of vigorously promoting the construction of ecological civilization, land consolidation in the construction of the constant pursuit of ecological design, to achieve sustainable use of land resources, China has made great progress in ecological land consolidation. In this paper, through the comparison of flow design and cross section design of agricultural canal design in ecological land remediation and traditional land remediation, the characteristic design of some agricultural canals in ecological land remediation was introduced, and the ecological, social and economic benefits of two land remediation methods were systematically analyzed. The analysis shows that ecological agricultural canals play a great role in protecting biodiversity, alleviating the contradiction between people and land, saving energy, purifying water resources and improving land quality, the research result has provided the basis and the model for the land consolidation in carrying on the ecology type ditch design.
\end{abstract}

\section{Keywords}

Agricultural Canal Design, Ecological Renovation, Comparative Study, Benefit Analysis

\section{Introduction}

Land consolidation has changed from simply guaranteeing agricultural development to meeting agricultural production needs and protecting sustainable 
development of ecosystem stability. In recent years, the construction of irrigation and water conservancy projects in China has made great achievements, but also accompanied by the deterioration of agricultural ecological environment conditions, biodiversity decline, serious agricultural non-point source pollution, water self-purification capacity decline and other problems. Ecotype land consolidation has become an important part of project construction, and it plays a great role in solving the contradiction between people and land, maintaining the dynamic balance of human activities and ecological environment, improving the quality of cultivated land, optimizing land structure, reducing energy consumption, protecting biodiversity and so on [1]. The ecological restoration technology and ecological engineering design in many developed countries are more mature, and applied to other similar fields. Although we have made good achievements, there is still a certain gap. Agricultural canal is an important part of farmland drainage and irrigation system, and it is also the main link to effectively reduce the collection of pollutants in farmland [2]. Therefore, the research on the design of ecological engineering of agricultural canal plays an important role in alleviating the problems of field ecological degradation, energy consumption and biodiversity reduction, realizing the efficient use of land resources, and maintaining and maintaining the balance of farmland ecosystem [3] [4] [5]. This paper systematically compares the traditional and ecological type of renovation in the design of agricultural canal engineering, and comparative analysis of both in the economic, ecological and social benefits, and provides the basis and reference for the design of ecological type of agricultural canal in land consolidation.

\section{Overview of the Study Area}

The research area is located between Changshe Mountain and Yuecheng Mountain in Lingchuan County, Guilin City, which belongs to hilly landform and mid-subtropical monsoon climate region, with distinct seasons, abundant heat resources, abundant rainfall, good water and heat conditions, and annual average temperature of $18.7^{\circ} \mathrm{C}$. The altitude of the area is between $156 \mathrm{~m}$ and $159 \mathrm{~m}$, and the topographic relief is small. The project area belongs to the residual hill slope area. Overlying clay, soil quality is relatively uniform, structure is good, general layer thickness is not large. The lower layer is argillaceous and carbonaceous limestone, partly carbonaceous shale and a small amount of siliceous rock. Rock is hard and brittle, thick, local through a small fault zone, karst development. The total area of the project area is 243.54 hectares, mainly arable land, with an area of 161.23 hectares, and there are also a certain number of barren grasslands, ponds, water surfaces and fields. The streams and ditches in the area flow continuously all the year round. During the rainy season from April to $\mathrm{Au}-$ gust, the precipitation is too concentrated and the water inflow is large, so there is often much water accumulated in the fields. The location map of the project area is shown in Figure 1. 


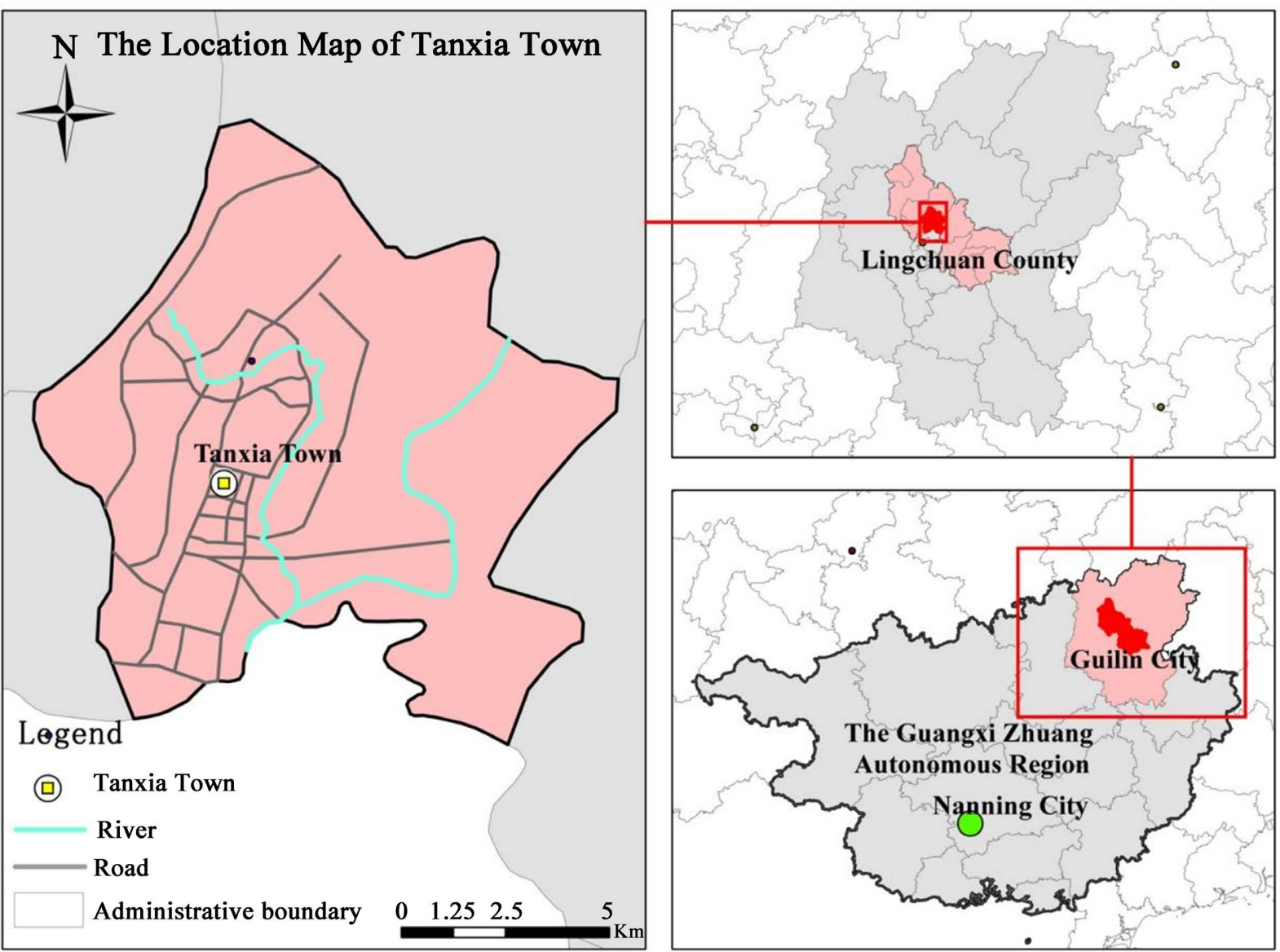

Figure 1. Location map of Tanxia Town.

\section{Comparison between Ecotype and Traditional Type of Agricultural Canal Design}

\subsection{Design Flow}

The discharge design of the agricultural canal is an important link in the construction of the agricultural canal, which has a close relationship with the irrigation demand, the increase of farmland output, and the investment cost of the canal system building. The comparative study of design flow shows the difference and advantage of the two kinds of ditches in irrigation benefit more directly.

\subsubsection{Design Discharge of Traditional Agricultural Canal}

The open channel uniform flow formula is used to calculate the discharge of the traditional agricultural canal: $Q=A C \sqrt{R i}$ [6], where $Q$ represents the design discharge of the canal $\left(\mathrm{m}^{3} / \mathrm{s}\right), A$ represents the cross section area of the canal $\left(\mathrm{m}^{2}\right), R$ represents the hydraulic radius $(\mathrm{m}), i$ represents the gradient of the channel bottom, and $C$ represents the Xie coefficient $\left(C=\frac{1}{n} R^{\frac{1}{6}}\right)$ [6].

According to the topographic conditions, $i$ is taken as $0.003, n$ is taken as 0.017 in the calculation of discharge design, and the design irrigation rate of the 
agricultural canal is $90 \%$.

Through calculation, the design flow of traditional agricultural canal is 0.176 $\mathrm{m}^{3} / \mathrm{s}$.

According to the calculation formula of flow velocity in Standard for Design of Irrigation and Drainage Engineering (GB50288-2018) calculate the average flow velocity of traditional agricultural canal $V=\frac{1}{n} R^{\frac{2}{3}} i^{\frac{1}{2}} \quad$ [6], where $R$ represents hydraulic radius $(\mathrm{m}), i$ represents gradient of canal bottom, and $n$ represents roughness of canal bed.

Through calculation, the average velocity of the traditional agricultural canal is $0.88 \mathrm{~m} / \mathrm{s}$, which is between the critical non-silting velocity $0.34 \mathrm{~m} / \mathrm{s}$ and the non-scouring velocity $3.0 \mathrm{~m} / \mathrm{s}$. It meets the requirements of anti-scouring and anti-silting.

\subsubsection{Design Flow of Ecological Agricultural Canal}

According to the "Land Consolidation Project Part 1: Construction Specifications" (DB45/T 1055-2014), its irrigation mainly adopts surface irrigation, the project area is mainly planted with rice, and the paddy field is rotated with single-season rice. In order to ensure the water supply to meet the needs of rice, the project design paddy field irrigation guarantee rate is $90 \%$. In addition to rice, there are a small number of dry land crops in the project area, which are single-season rotation crops. In the project area, the water consumption of crops in peak period is $110 \mathrm{~m}^{3} / \mathrm{hm}^{2}$, the utilization coefficient of canal system water is 0.75 , and the flow of agricultural canal is calculated [7] [8] [9] [10] [11].

According to the flow formula $Q_{n}=\frac{N q_{s} \bar{A}_{n}}{\eta_{n}}$ [12] of rotation irrigation canal in the Standard for Design of Irrigation and Drainage Engineering (GB50288-2018), the design flow of ecological agricultural canal is calculated, in which $Q_{n}$ represents the design flow of canal $\left(\mathrm{m}^{3} / \mathrm{s}\right), N$ represents the number of rotation irrigation groups, $q_{s}$ represents the design irrigation rate $\left[\mathrm{m}^{3} /(\mathrm{s}\right.$. $\left.\left.100 \mathrm{hm}^{2}\right)\right], \bar{A}_{n}$ represents the average irrigation area of rotation irrigation groups $\left(100 \mathrm{hm}^{2}\right), \eta_{n}$ represents indicates the irrigation water efficiency.

Through calculation, the design flow of ecological agricultural canal is 0.301 $\mathrm{m}^{3} / \mathrm{s}$.

Considering the design material, design form, geological and topographic conditions of ecological agricultural canal, $i$ takes $0.002, n$ takes 0.028 . Using the formula $Q=A C \sqrt{R i}$ to calculate the flow through the channel, the $Q$ is $0.312 \mathrm{~m}^{3} / \mathrm{s}$.

According to the calculation formula of channel flow velocity, the average velocity of ecological agricultural canal is $0.651 \mathrm{~m} / \mathrm{s}$, and the flow velocity is between the allowable non-deposition velocity $0.3 \mathrm{~m} / \mathrm{s}$ and the allowable non-scouring velocity $6.0 \mathrm{~m} / \mathrm{s}$.

Through the above calculation and comparison, the design flow of ecological agricultural canal is larger than the design flow of traditional agricultural canal, and the flow velocity is small. The design flow of ecological type of agricultural 
canal not only meets the requirements of farmland irrigation water demand, but also reduces the flow rate in the canal and meets the requirements of anti-erosion and anti-silting of the canal, and increases the ecological service function of the agricultural canal, which plays an important role in ecological environment protection.

\subsection{Cross Section Design Comparison}

\subsubsection{Cross Section Design of Traditional Agricultural Canal}

In order to facilitate gravity flow irrigation, the design elevation of traditional agricultural canal is higher than that of field tillage layer when the terrain conditions permit, so as to ensure the stability of field irrigation canal foundation. In order to reduce the damage of the canal caused by external factors, the foundation of the canal must be tamped to make the canal have a stable structure, meet the requirements of agricultural production and meet the requirements of seepage and erosion prevention. The bottom of the canal is lined with C15 concrete with a thickness of $0.08 \mathrm{~m}$ (Figure 2). In order to avoid the destruction of the agricultural canal and the decrease of the utilization rate due to the uneven settlement of the foundation, temperature change and other factors, which will affect the irrigation demand of farmland, the agricultural canal is designed to set up settlement joints at the bottom of the canal and expansion joints at the shoulder of the canal, so as to ensure the normal use of the agricultural canal and reduce the destruction caused by external factors.

All the traditional agricultural canals basically adopt the three-side light anti-seepage technology, which improves the water utilization coefficient of canal system in the project area and meets the requirements of basic farmland construction.

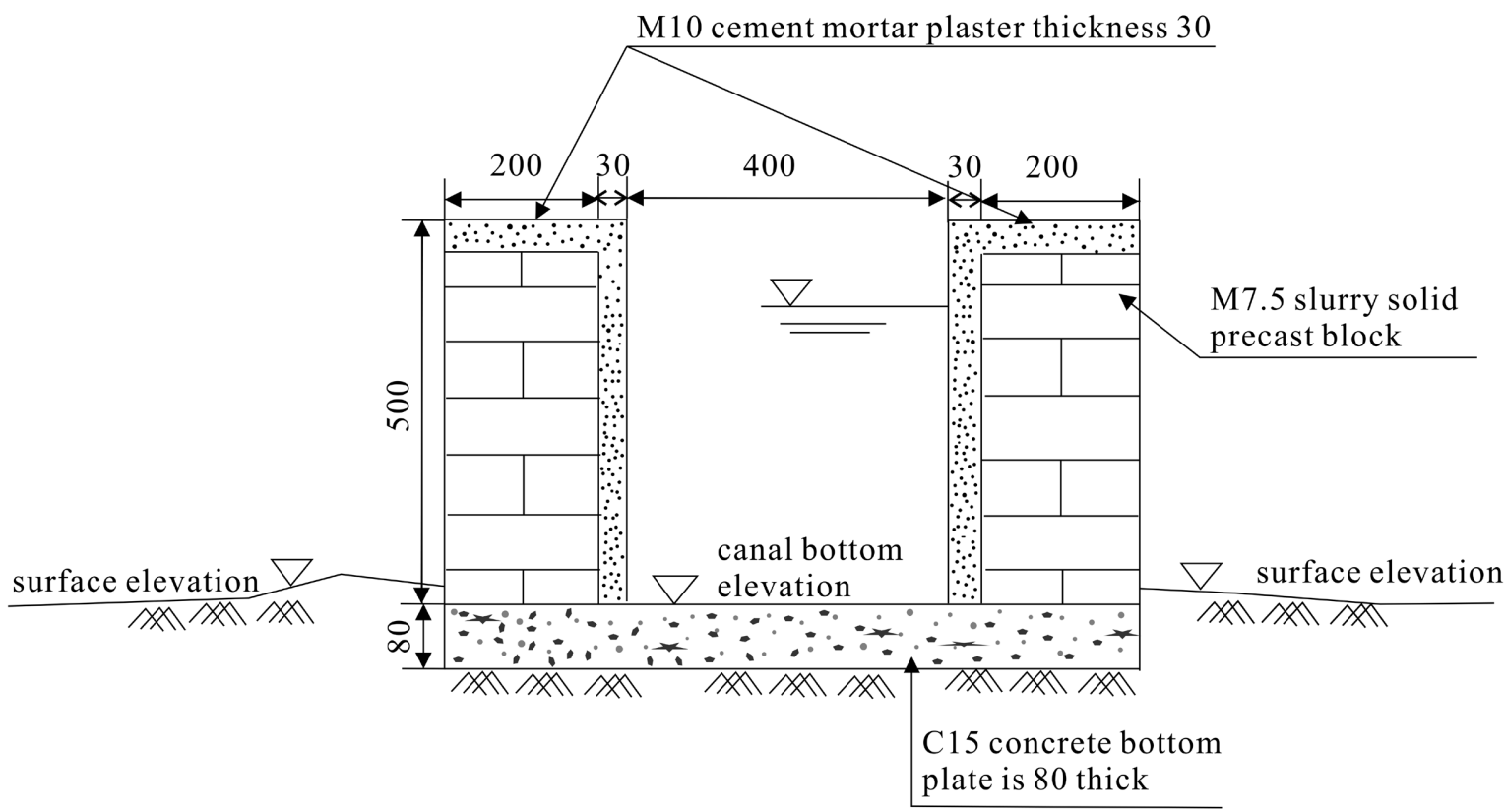

Figure 2. Cross-section of traditional agricultural canal (unit: $\mathrm{mm}$ ). 


\subsubsection{Cross Section Design of Ecological Agricultural Canal}

The ecological type agricultural canal is of a trapezoidal section structure and adopts a buckle ecological brick lining mode, the width of the canal is designed to be $0.5 \mathrm{~m}$, the depth of the canal is $0.6 \mathrm{~m}$, and the slope protection of the buckle ecological lining with a thickness of $0.08 \mathrm{~m}$ is arranged. The design of the canal shoulder is $0.2 \mathrm{~m}$ wide and $0.1 \mathrm{~m}$ thick, and the C20 concrete is used for pouring and capping. The width of the canal bank is designed to be $0.5 \mathrm{~m}$. C20 cast-in-situ concrete shall be used for anti-skid at both sides of the canal bottom. The middle part of the canal bottom is backfilled with $0.2 \mathrm{~m}$ deep gravel and soil (Figure 3). The ecological holes and the backfilled soil at the bottom of the canal are reserved by using the buckle ecological bricks, so that water seepage is facilitated, vegetation coverage in the ecological holes is facilitated, a natural buffer zone is formed, and the water holding capacity of the agricultural canal is improved. Reserved plant growth space on both sides of the canal top enhances the ecological efficiency of the agricultural canal [13] [14].

Eco-type agricultural canals basically adopt eco-type materials and natural materials, greatly reducing the use of concrete. Through the use of soil adsorption, plant absorption, microbial decomposition and other functions to reduce farmland pollution and protect the ecological environment of agricultural canals [15].

\section{Characteristic Design of Agricultural Canal in Ecotype Renovation}

Agricultural canal is the separation zone between farmland and farmland, so we should make good use of the special location of agricultural canal to create a small ecological circle suitable for biological life, so that the agricultural canal has the function of protecting biodiversity [16].

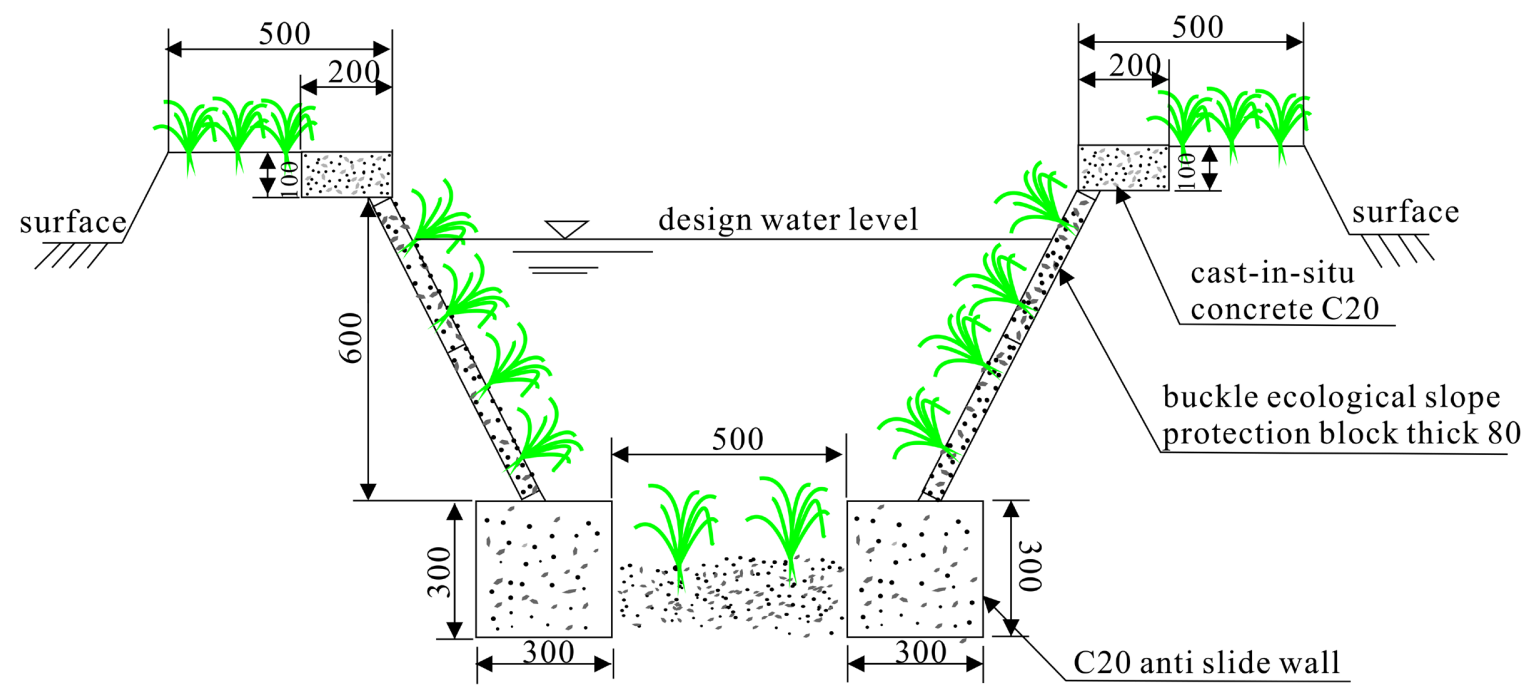

Figure 3. Cross-sectional view of ecological agricultural canal (unit: $\mathrm{mm}$ ). 


\subsection{Setting of Biological Pond}

Rectangular biological ponds with a depth of about $0.3 \mathrm{~m}$ will be planned and designed every $30 \mathrm{~m}$ (Figure 4). The agricultural canal is built with hollow bricks to provide a good living environment for organisms. When the agricultural canal is drained, the residual water in the biological pond provides habitat for fish, shrimp and other organisms.

\subsection{Setting of Biological Corridor}

Biological corridors are arranged every $50 \mathrm{~m}$ on both sides of the ecological agricultural canal. The biological corridors are designed in the form of steps. Each step is designed to be $0.1 \mathrm{~m}$ wide and $0.05 \mathrm{~m}$ high. The steps are troweled with $0.03 \mathrm{~m}$ thick $\mathrm{C} 15$ concrete (Figure 5), and the organisms can climb out smoothly through the steps. The establishment of biological channels in the design of ecological agricultural canals effectively solves the problem that it is difficult for organisms to escape from the canals [17].

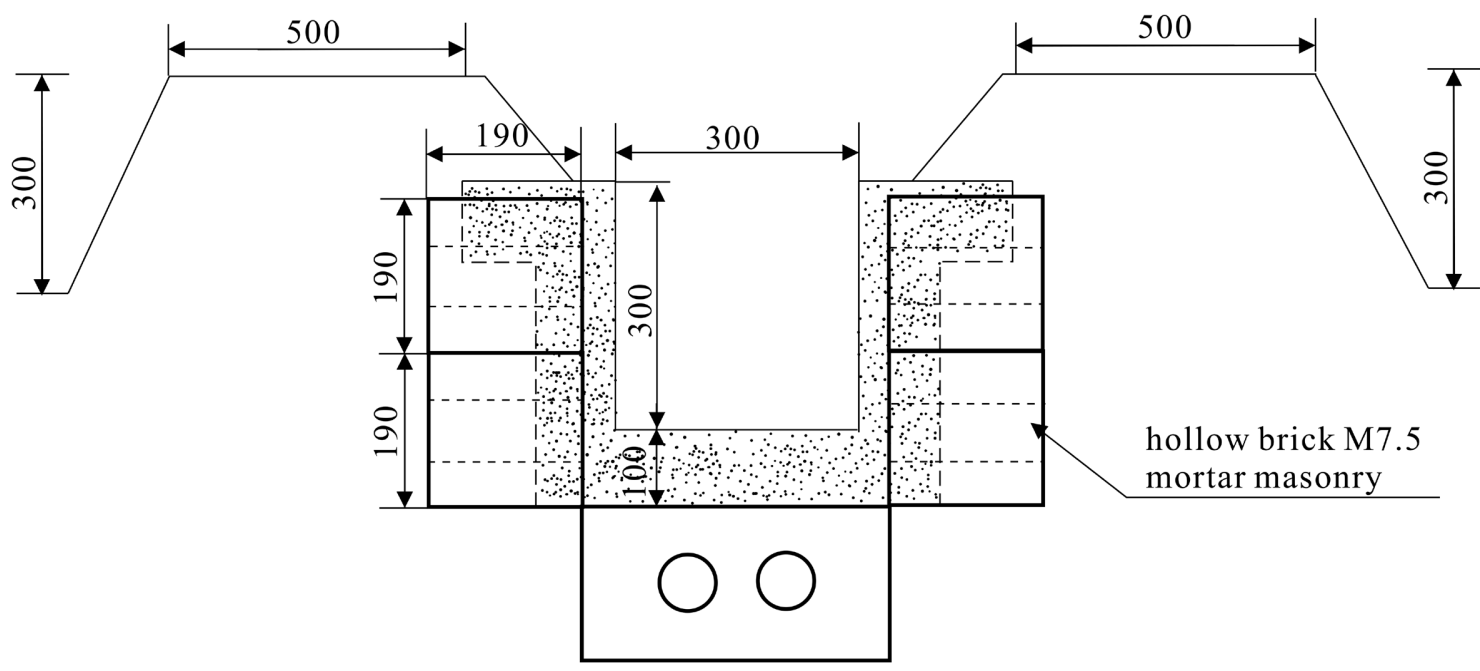

Figure 4. Sectional view of the biological pond (unit: $\mathrm{mm}$ ).

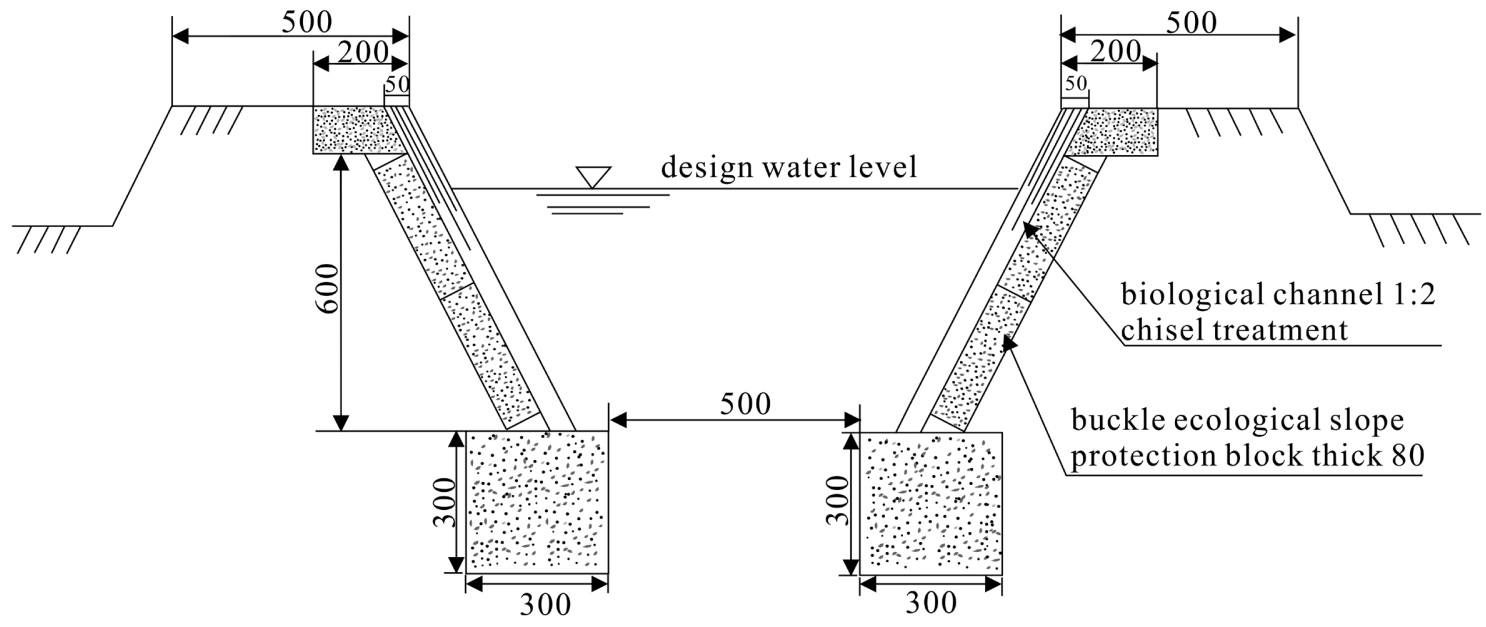

Figure 5. Cross-sectional view of agricultural canal biological corridor (unit: $\mathrm{mm}$ ). 


\section{Discussion and Analysis}

\subsection{Ecological Benefit}

1) Eco-type agricultural canals adopt the design concept of water resources and environmental protection. Compared with the traditional cast-in-situ masonry method, the channel structure is stable and the anti-seepage and anti-erosion function is better. The design of the ecological regulation agricultural canal adopts the prefabricated buckle ecological brick lining canal, and the material reserves the ecological hole design to reserve the living space for the aquatic plants, which is beneficial to removing the water logging of the farmland and enhancing the purification effect of the agricultural canal on the water source pollution [18] [19].

2) More attention should be paid to the protection of ecological environment in the design of ecological agricultural canals. The ecological agricultural canal will increase the design of biological ponds and biological escape channels, which is more focused on the ecological importance than the traditional three-sided light anti-seepage technology, while reducing the use of concrete, reducing carbon emissions and energy consumption, in line with the concept of sustainable development in the new era. This design will provide a good habitat for organisms, create escape conditions, protect the normal exchange between organisms in the ecosystem, and maintain the stability of the ecosystem [20].

\subsection{Social Benefit}

1) Traditional agricultural canals use a lot of concrete, while ecological agricultural canals use ecological hole bricks, which follow the requirements of vigorously promoting the construction of ecological civilization, increase the demand for ecological materials and natural green materials, effectively promote the development of industry and related technologies, promote social development and progress, and promote socialist modernization [21].

2) The construction of ecological agricultural canal has further optimized the situation of effectively reducing farmland pollution, reducing the use of pesticides, purifying water resources, better ensuring the green health of agricultural products, reducing the occurrence of food safety problems in society, and promoting social harmony and stability.

3) The construction of ecological agricultural canal has effectively improved the contradiction between people and land and the conditions of agricultural production, so that the essential land and water resources in agricultural production can be used more scientifically and rationally, at the same time, the improvement of ecological agricultural canal provides a reference for the scientific improvement of other social production activities, and provides impetus for the scientific production and construction [22].

\subsection{Economic Benefit}

According to "Guilin City Construction Project Cost Information" (May 2009), 
the paper calculates the investment level index of agricultural canal units to analyze the economic benefits [23].

Taking this project area as an example, the total budget of traditional agricultural canal engineering design project is 439,600 yuan, and 9 new agricultural canals are built, with a total length of $3234.78 \mathrm{~m}$. Through calculation, the unit investment of traditional type of agricultural canal is 135.90 yuan $/ \mathrm{m}$. The ecological type agricultural canal adopts the buckle ecological brick lining mode, and each ecological brick is priced at 19 yuan, through calculation, the unit investment of the ecological type agricultural canal is $106.4 \mathrm{yuan} / \mathrm{m}$, and compared with the traditional agricultural canal, the fund is saved by $29.5 \mathrm{yuan} / \mathrm{m}$. According to the project implementation experience, the total investment budget of ecological type of agricultural canal in the project area is 344,200 yuan, ecological type of agricultural canal using ecological lining, and the use of ecological materials, can save 95,400 yuan of construction costs, accounting for $2 \%$ of the construction costs. In the construction process, through the improvement and improvement of construction technology and the purchase and use of ecological materials, it is estimated that about $5 \%$ of the investment can be saved [24].

\section{Concluding Remark}

Through the comparative study of ecological and traditional agricultural canal design, the ecological agricultural canal shows great advantages in protecting biological diversity, alleviating the contradiction between man and land, saving energy, purifying water resources and improving land quality. In recent years, the integration of ecological protection and land consolidation, drainage and irrigation engineering design is an important part of land consolidation. Therefore, the ecological agricultural canal design in irrigation system can improve the agricultural canal design technology and process, enhance the ecological service function of the agricultural canal, pursue the concept of sustainable development, and form the harmonious development environment of regional people and land.

\section{Conflicts of Interest}

The authors declare no conflicts of interest regarding the publication of this paper.

\section{References}

[1] Wu, W., Cai, G., Liu, T. and Liu, S. (2019) Analysis on Irrigation and Drainage Engineering of Land Consolidation Project in Guizhou Province from Ecological Perspective. Rural Economy and Technology, 30, 67-69.

[2] Gao, T. (2019) The Exploration of Ecotype Land Consolidation Planning and Design. Urban Construction Theory Research, No. 22, 13-14.

[3] Wang, L. (2020) Analysis of Ecotype Land Consolidation Planning and Design Model. Shanxi Agricultural Economy, No. 11, 90-92.

[4] Zhang, S. (2019) Design of Irrigation and Drainage System in Land Consolidation 
Project. Southern Agriculture, 13, 177-178.

[5] Xie, X. (2008) Study on the Impact of Irrigation and Water Conservancy Construction on Agricultural Ecological Environment. Hehai University, Nanjing.

[6] The Ministry of Housing and Urban-Rural Development of China (2018) GB 50288-2018, Design Standard for Irrigation and Drainage Engineering.

[7] Liu, Y. (2020) Discussion on the Realization of Ecological Land Consolidation Planning. Science and Wealth, No. 6, 357.

[8] Wang, X. (2014) Planning Design and Benefit Analysis of Ecological Land Consolidation Project. Hunan Agricultural University, Changsha.

[9] Wang, L. and Xuan, B. (2010) Thinking of Design Discharge Calculation Method of Rotation Irrigation Channel. Jilin Water Conservancy, No. 8, 35-36.

[10] Zhang, R., Wu, H. and Lin, Y. (2018) Calculation and Analysis of Design Discharge of Zhangzhuang Irrigation District in Qingzhou. Shandong Water Conservancy, No. 9, 3-4.

[11] Yue, X., Liu, X., Liu, Y. and Zhu, Z. (2012) Design of Water Transmission and Drainage Engineering in Land Consolidation Project. Anhui Agricultural Sciences, 40, 17375-17377.

[12] Administration of Quality and Technical Supervision of Guangxi (2014) DB 45/T 1055-2014, Land Consolidation Engineering-Part 1: Construction Standard.

[13] Xie, B. (2011) Calculation and Analysis of Design Discharge of Irrigation Channel. Shanxi Water Conservancy, No. 4, 175-176.

[14] Xiao, F. and Zhai, Y. (2017) Canal Design and Construction Management in Irrigation and Drainage Engineering Design. Jiangxi Agriculture, No. 22, 49.

[15] Song, W. (2019) Discussion on Optimal Design of Irrigation and Drainage Project. Science and Technology, No. 24, 192-193.

[16] Zhang, T. (2018) Research Progress on Ecological Design of Irrigation Canal. Architectural Engineering Technology and Design, No. 32, 3907.

[17] Zhang, D. (2019) Study and Application of New Method for Optimal Design of Irrigation and Drainage Project. Gansu Science and Technology, 48, 10-12.

[18] Ma, J. and Liu, J. (2018) Empirical Study on Ecological Land Consolidation Planning and Design: A Case Study of Chongqing. Land and Resources Information, No. 3, 40-44.

[19] Deng, B. and Jing, J. (2020) Study on Ecological Design of Land Consolidation. Shanxi Architecture, 46, 14-15.

[20] Yao, C. (2020) Comprehensive Benefit Analysis of Land Consolidation Project in Zichang City. Anhui Agronomy Bulletin, 26, 109-112.

[21] Yang, M., Wu, K., Li, C., Liu, P. and Zhu, P. (2017) Biodiversity Protection in Land Consolidation. China Agricultural Resources and Regional Planning, No. 2, 28-33.

[22] Li, S., Ju, Z. and Zhang, X. (2015) Benefit Analysis of Land Consolidation Projects Based on Provincial Differences. Journal of Shaanxi Normal University, 43, 93-97.

[23] Huang, H., Wu, C. and Zhang, S. (2012) Analysis and Evaluation of Land Consolidation Planning Benefit in Heilongjiang Province. Journal of Agricultural Engineering, 28, 240-246.

[24] Lu, W., Fan, Y., Wang, M. and Nie, J. (2016) Economic Benefit Evaluation of Rural Land Consolidation Project: A Case Study of Sishilijie Town, Poyang County, Jiangxi Province. Resource Information and Engineering, 31, 105-108. 